症例

下行結腸固定不全を合併した左傍十二指腸ヘルニアの 1 例

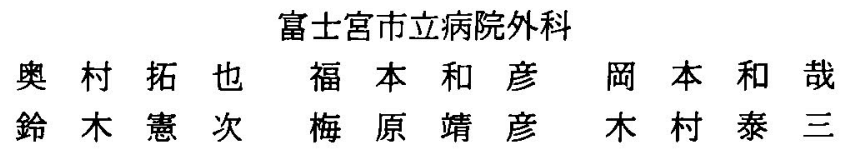

症例は39歳の女性．急性腹症で当院救急外来を受診した．腹部 CT にて下行結腸の走 行異常と胃と脺の間にある小腸拡張を認めた，腹痛は改善したため，入院し精查を行っ た. 腹痛発作時に行った CT て下腸間膜静脈に向かう小腸の毫状㹡張を認め, 下行結腸 間膜固定不全を合併した左傍十二指腸へルニアと診断した。開腹所見では，下行結腸固 定不全と，回腸末端を除く全小腸が下腸間膜静脈の背側を潜って下行結腸間膜の左側に 変位していた，空腸起始部から $110 \mathrm{~cm}$ まで小腸はへルニア蒹を有していたが，それ以 下の小腸は遊離腹腔に面していた．腸管整復後下行結腸の固定と下行結腸間膜の欠損孔 を閉鎖した。

左傍十二指腸へルニアは下腸間膜静脈をへルニア門の前縁とするが, 本症例ではへル ニア毫を有する部分と遊離腹然に面する部分の二成分より構成されており，左傍十二指 腸ヘルニアの亜型と考えられた。

索引用語：左傍十二指腸ヘルニア, 結腸固定不全

はじめに

傍十二指腸ヘルニアは腸管走行異常を合併すること が多いとされる.今回下行結腸固定不全を合併した左 傍十二指腸へルニアを経験したので報告する。

\section{症例}

患者：39歳，女性.

主訴：腹痛。

既往歴：特になし。

現病歴：平成 6 年に原因不明のイレウスにて内科入 院.

平成13年12月11日腹痛にて当院救急外来受診した が,すぐに軽快したため㷌宅した。同月15日AM 5：00 頃突然の腹痛にて当院救急外来受診し, 緊急入院とな った.

入院時現症：左側腹部に弾性軟の圧痛を伴う腫瘤を 触知したが，反跳痛，筋性防御は認めなかった。

血液生化学検查 : CPK (162IU/1) と LDH (233IU/

1) の軽度上昇以外に，異常を認めなかった。

\section{5 年 1 月 17 日受付 2005 年 3 月 7 日採用 \\ 〈所属施設住所〉}

₹418-0076 富士宮市錦町 3-1

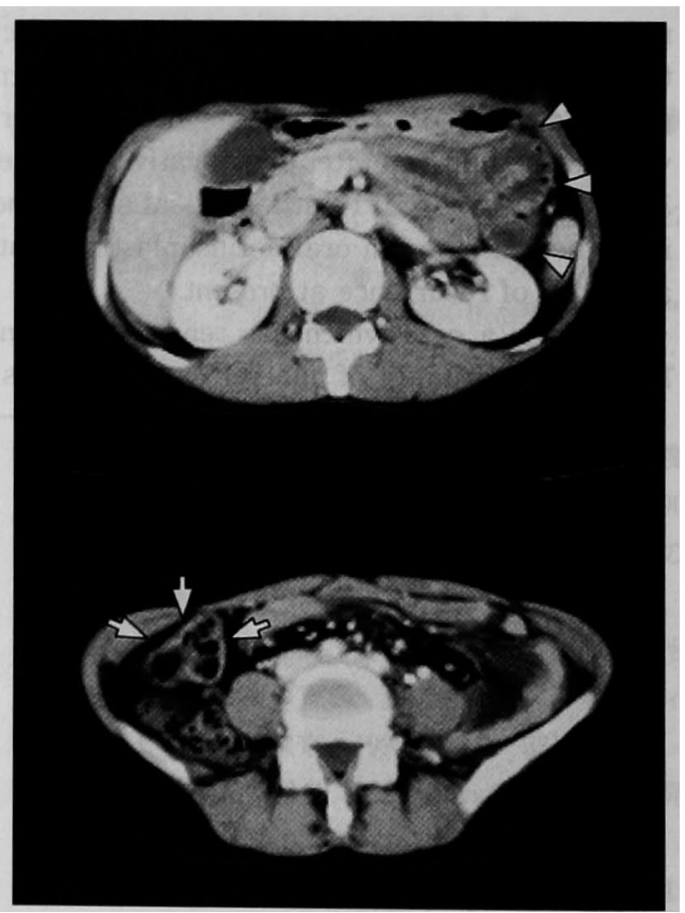

图 1 来院時腹部 CT：胃と墙の間に㹡張した小腸 (矢頭)を認めた。 上行結腸と下行結腸が右側腹腔 内を併走する走行異常（矢印）を認めた。 


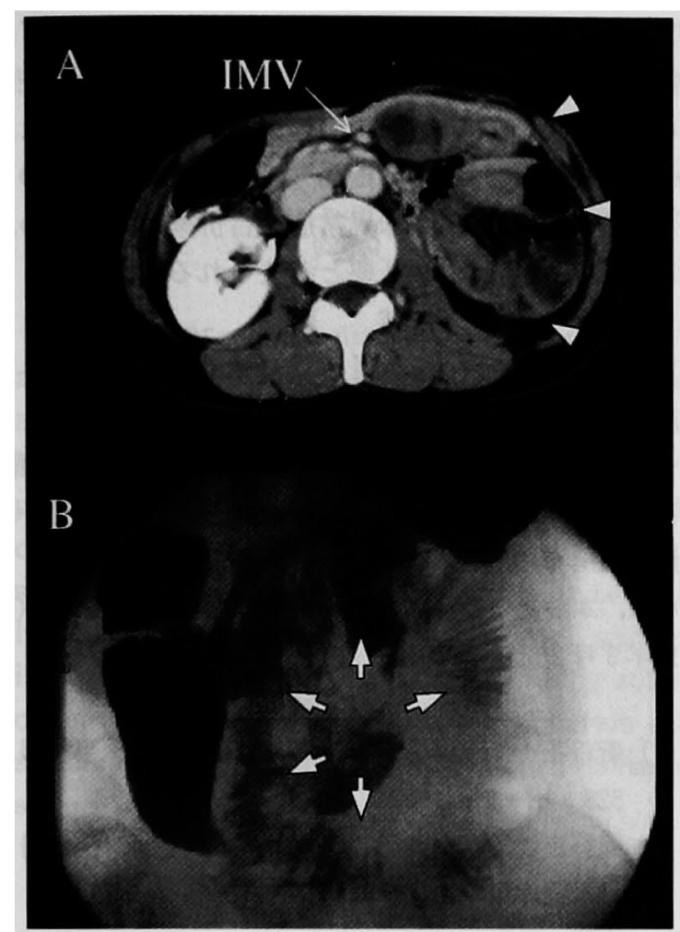

図 $2 \mathrm{~A}$ 腹痛時腹部 CT: 下腸間膜静脈 (IMV) に向 かって収束する哄状の小腸拡張 (矢頭).

B 腹痛時胃小腸造影：背側より円孤状の小腸 により圧排される胃（矢印）

腹部単純 X 線検查：立位, 臥位ともに異常を認めな かった。

腹部超音波検查 : 左側腹部の腫溜部に拡張した腸管 を認めたが，それ以外に異常所見は認めなかった。

入院後経過：発症 3 時間後に腹部 CT 検查を行った (図 1 ).上行結腸と下行結腸が右側腹腔内を併走する 走行異常を認めた。胃と膵の間に抎張した小腸を認め た．腹水は認めなかった，腸回転異常症もしくは左傍 十二指腸ヘルニアによる腸捻転を疑ったが，検査後腹 部腫瘤と腹部所見は完全に消失していた。腹痛のない 時の小腸透視では，十二指腸から上行結腸までの走行 に異常はなかった，それ以後の結腸は横走せず, 上行 結腸に平行して腹部右側を下行し，直腸に通じた．腹 痛発作時にも腹部造影 CT および小腸透視を行った。 CT では下腸間膜静脈に向かって収束する嚲状の小腸 拡張を認め，左傍十二指腸ヘルニアと診断した（図 2 A)。腹痛時の胃小腸透視では, 胃は円孤状に背側より 圧排され, Trietz 靯帯から十数 $\mathrm{cm}$ の空腸で造影剤は 途絶していた(図 2 B). 腹痛の消失ともに円孤状の空

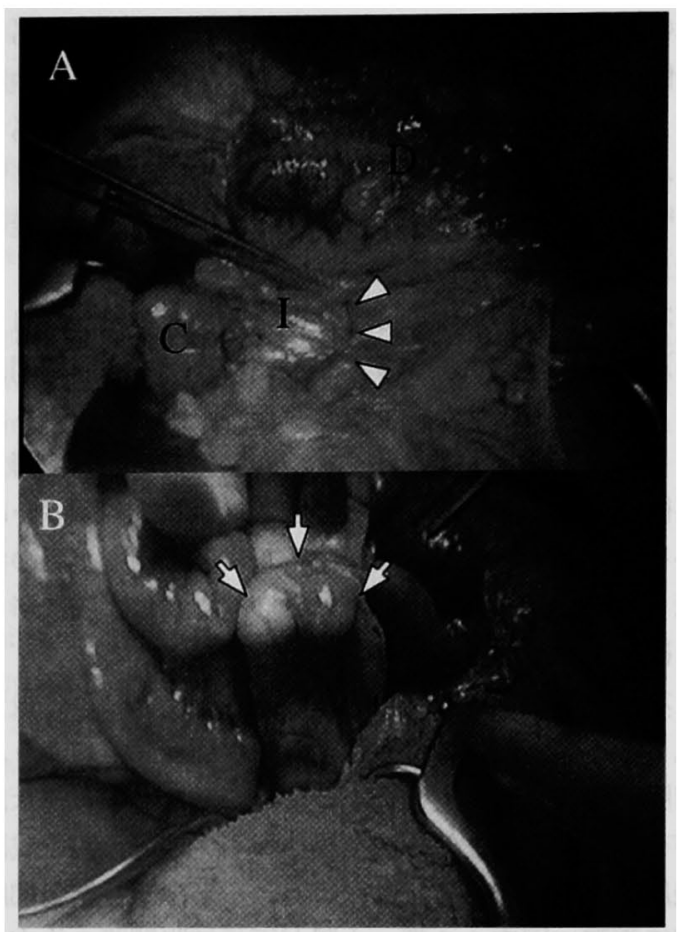

図 3 術中写真：A）ヘルニア門を構成する下腸間 膜静脈 (矢頭)。固定されていない下行結腸 (D)。 ヘルニア門の右側に位置する回腸末端 (I) と盲腸

（C)．B）起始部より $110 \mathrm{~cm}$ まての空腸を覆うへ ルニア趸（矢印）。

腸拡張は消失した，腸捻転を繰り返す左傍十二指腸へ ルニアと診断し，平成13年12月手術を行った。

手術所見：腹腔鏡下に整復を試みたが，不能であっ たので開腹に移行した，開腹したところ，下行結腸は 固定されておらず，回腸末端を除く全小腸は，下腸間 膜静脈の背側を潜って下行結腸間膜の左側に变位して いた（図 $3 \mathrm{~A}$ )。空腸起始部から $110 \mathrm{~cm}$ までの小腸はへ ルニア襄を有していたが，それ以下の小腸は遊離腹腔 に面していた(図 $3 \mathrm{~B}$ )。手術はへルニア变を切開開放 し, 全小腸を正常位に整復後，下行結腸間膜の欠損孔 を閉銷し，下行結腸を腹腔内左側に固定して手術終了 した.

術後経過：術後は順調に経過し, 第17病日に退院し た。術後 2 年腹痛発作を認めていない.

$$
\text { 考察 }
$$

傍十二指腸ヘルニアは1857年に Treitz が報告し, 本 邦では1902年の新谷”の報告が初めてとされている。 本邦では傍十二指腸ヘルニアは現在までに100症例以 
上の報告があり，我が国の集計では左側が約 $61.1 \%$ と 右側の1.57倍て，男女比については $3.65 ： 1$ と男性に 多く, 発症頻度については成人までの発症が $33.9 \%$ と され，成人以上でも若い世代に多いと報告されてい ろ . この報告によれば, 自験例のような 30 歳代発症は $12.6 \%$ とされている.

本症の症状については急性腹症としての腹痛 (81.8 \%), 嘔吐 (64.2\%) が多く, 長期にわたる病悩期間が あり, 腹痛, 嘔吐を繰り返しながら, 術前に診断され ることが少なく，通常はイレウス症状をきたして緊急 手術となることが多い3). 自験例の症状である増悪・改 善を繰り返す急激な腹痛は, ヘルニア萧内で小腸の捻 転・解除を繰り返したためでありこれれ小腸造影に て確認することがてきた.

本症の発生機序に関しては腹腔内圧上昇による後天 説もあるが，近年では胎生期の中腸回転異常に伴う， 結腸間膜固定時の異常によって起こったとする先天説 が有力である. 左傍十二指腸ヘルニアの先天説の成因 機序は中腸の回転は正常に行われるが，下行結腸間膜 が後腹膜に固定する際, 小腸が下行結腸間膜の後方に 入り込んでしまい，下行結腸間膜に包まれて後腹壁に 閉じこめられた形になり，ヘルニア門の辺緑には下腸 間膜静脈と左結腸動脈が走行する形となる゙。自験例 は下行結腸の後腹膜固定不全があり，ほほ全小腸が下 腸間膜静脈および左結腸動脈を前緑とするへルニア門 を通って左側に位置していたことから, 胎生期の下行 結腸固定時期に小腸全体が下行結腸間膜と後腹膜の間 に入り込んだため，小腸全体がヘルニア内容に相当す る左傍十二指腸へルニアが形成されたと推測される。 しかし, 本来なら小腸のほとんどがへルニア㱏に被覆 されるべきものであるが，へルニア集内の小腸は空腸 起始部から $110 \mathrm{~cm}$ の小腸にすきず，それ以下の小腸は 遊離腹腔内に面していた。この点で左傍十二指腸へル ニアの亜型であると推測した。このような症例報告は みられなかった。

本症の診断には最近では CT が有用とする報告が多 (25) 7). 胃と脺葴の間に存在する衰状の小腸拡張と下 腸間膜静脈の背側に走行する小腸が認められれば左傍 十二指腸へルニアと診断することができる．本症例て もCTで同様の所見を認められた。

本症の治療はへルニア内容を正常位置に整復し, へ ルニア門を閉鎖することである゙．最近では腹腔鏡補 助下に行われた症例報告も散見される ${ }^{9 / 10)}$. 今回の症
例では腹腔鏡下に観察し，整復する時点でヘルニア門 と小腸の瘜着が存在したため開腹したが，今後腹腔鏡 下の整復・ヘルニア門閉鎖の術式が増加するものと思 われる.しかし，傍十二指腸ヘルニアでは自験例のよ うな無型も含め, 腸回転異常症の合併率が高いため, 全小腸の入念な観察が肝要と考えられる.

\section{結語}

下行結腸固定不全を合併した左傍十二指腸へルニア を経験した。

ヘルニア内容はヘルニア喜を有する部分と遊離腹腔 に面した部分の二成分より構成されており，左傍十二 指腸ヘルニアの亜型と考えられた。

なお，本論文の要旨は静岡県外科医会第191回集談会 (平 成14年 3 月 2 日）にて報告した。

\section{文献}

1）新谷正吉：空腸十二指腸藏・嵌頓。中外医事新報 $528: 18-19,1902$

2）間野正之, 西 英行：傍十二指腸ヘルニア. 別冊 日本臨林領域別淀候群シリーズ, 5 , 日本臨林社, 大阪, 1994, p823-825

3）伊藤義也，黒山信一，中村孝伸他：絞拒性イレウ スをきたした右十二指腸傍へルニアの 1 例. 日臨 外会誌 $58: 1519-1522,1997$

4) Davis R: Surgery of left paraduodenal hernia. Am J Surg $129: 570-573,1975$

5) 安藤敏典, 菊池 淳, 竹村真一：術前診断しえた 左傍十二指腸へルニアの 1 例. 日臨外会誌 64 ： 2759-2762, 2003

6）大楽耕司, 岸川正彦, 榎 忠彦他：術前診断が可 能であった左傍十二指腸へルニアの 1 例. 日臨外 会誌 $64: 1903-1906,2003$

7）沖野由理子, 足立覀紀子, 森 宣：ヘルニアの 画像診断 腹部のヘルニア. 臨放線 $48: 718-$ 728, 2003

8）遠近直成, 公文正光, 荒木京二郎：左傍十二指腸 ヘルニアの1例. 日臨外会誌 $57: 389-392,1996$

9）山口智弘, 内藤弘之, 遠藤善裕地：術前 CT 画像 にて疑われた，左傍十二指腸へルニアの1例. 日 臨外会誌 $63: 1901-1904,2002$

10）中西 史, 三井一浩, 松本宏他：左傍十二指腸 ヘルニアの 2 例一開腹手術の 1 例と腹势鏡下手術 の1例一. 日臨外会誌 $63: 1302-1307,2002$ 


\title{
A CASE OF LEFT PARADUODENAL HERNIA WITH MOBILE OF THE DESCENDING COLON
}

\author{
Takuya OKUMURA, Kazuhiko FUKUMOTO, Kazuya OKAMOTO, \\ Kenji SUZUKI, Yasuhiko UMEHARA and Taizo KIMURA \\ Department of Surgery, Fujinomiya City General Hospital
}

\begin{abstract}
A 39-year-old woman was admitted to the hospital because of acute abdomen. Abdominal CT scan at arrival showed mobile of the descending colon and dilation of the small intestine between the stomach and pancreatic body and tail. Abdominal CT scan at abdominal attack showed the dilated small intestine that converged toward the inferior mesentric vein (IMV). Therefore she was diagnosed as having left paraduodenal hernia with mobile of the descending colon. Laparotomy showed mobile of the descending colon and the entire small intestine except for the end of the ileum that which was dislocated to the left side of the descending colon passed from behind the IMV. The small intestine by $110 \mathrm{~cm}$ from the Treitz ligament was covered with hernial sac, and the remaining small intestine was uncovered. After the intestine was repositioned, the descending colon was fixed and a deficit on the mesentery of descending colon was closed. Left paraduodenal hernia usually has a hilum of which anterior wall consist of IMV, so this case was diagnosed as left paraduodenal hernia with two components with and without hernial sac.
\end{abstract}

